\title{
Mechanism of Shortened Bones in Mucopolysaccharidosis VII
}

\author{
Jason A. Metcalf ${ }^{\mathrm{a}}$, Yanming Zhang ${ }^{\mathrm{a}}$, Matthew J. Hilton $^{\mathrm{a}, \mathrm{b}}$, Fanxin Long ${ }^{\mathrm{a}, \mathrm{c}}$, and Katherine $\mathbf{P}$. \\ Pondera,d \\ aDepartment of Medicine, Washington University School of Medicine, St. Louis, MO, USA \\ ${ }^{b}$ Center for Musculoskeletal Research, University of Rochester, Rochester, NY, USA \\ 'Department of Developmental Biology, Washington University School of Medicine, St. Louis, MO, \\ USA \\ dDepartment of Biochemistry and Molecular Biophysics, Washington University School of Medicine, \\ St. Louis, MO, USA
}

\section{Abstract}

Mucopolysaccharidosis VII (MPS VII) is a lysosomal storage disease in which deficiency in $\beta$ glucuronidase results in glycosaminoglycan (GAG) accumulation in and around cells, causing shortened long bones through mechanisms that remain largely unclear. We demonstrate here that MPS VII mice accumulate massive amounts of the GAG chondroitin-4-sulfate (C4S) in their growth plates, the cartilaginous region near the ends of long bones responsible for growth. MPS VII mice also have only $60 \%$ of the normal number of chondrocytes in the growth plate and $55 \%$ of normal chondrocyte proliferation at 3 weeks of age. We hypothesized that this reduction in proliferation was due to C4S-mediated overactivation of fibroblast growth factor receptor 3 (FGFR3). However, MPS VII mice that were FGFR3-deficient still had shortened bones, suggesting that FGFR3 is not required for the bone defect. Further study revealed that MPS VII growth plates had reduced tyrosine phosphorylation of STAT3, a pro-proliferative transcription factor. This was accompanied by a decrease in expression of leukemia inhibitory factor (LIF) and other interleukin 6 family cytokines, and a reduction in phosphorylated tyrosine kinase 2 (TYK2), Janus kinase 1 (JAK1), and JAK2, known activators of STAT3 phosphorylation. Intriguingly, loss of function mutations in LIF and its receptor leads to shortened bones. This suggests that accumulation of $\mathrm{C} 4 \mathrm{~S}$ in the growth plate leads to reduced expression of LIF and reduced STAT3-tyrosine phosphorylation, which results in reduced chondrocyte proliferation and ultimately shortened bones.

\section{Keywords}

Mucopolysaccharidosis (MPS); Signal Transducer and Activator of Transcription (STAT); Fibroblast Growth Factor Receptor (FGFR); Glycosaminoglycan (GAG); Growth Plate; Dysostosis Multiplex

Corresponding Author: Jason Metcalf, Campus Box 8125, 660 South Euclid Avenue, Saint Louis, MO 63110, Tel: (314) 362-5188, Fax: (314) 362-8813, jametcal@wustl.edu, kponder@dom.wustl.edu.

Publisher's Disclaimer: This is a PDF file of an unedited manuscript that has been accepted for publication. As a service to our customers we are providing this early version of the manuscript. The manuscript will undergo copyediting, typesetting, and review of the resulting proof before it is published in its final citable form. Please note that during the production process errors may be discovered which could affect the content, and all legal disclaimers that apply to the journal pertain. 


\section{INTRODUCTION}

The mucopolysaccharidoses (MPS) are a family of lysosomal storage diseases that result from the deficiency of enzymes that degrade glycosaminoglycans (GAGs) [1] and occur in 1 in 25,000 live births [2]. GAGs accumulate in the lysosome, leading to dysfunction in a variety of cell types and organs through mechanisms that generally remain unclear. Symptoms of MPS vary according to the specific disease, but can include hepatosplenomegaly, corneal clouding, growth and mental retardation, cardiac defects, and bone malformations collectively known as dysostosis multiplex [1].

Dysostosis multiplex can involve short bones, thick bones, and bones with abnormal shape. The severity and characteristics of dysostosis multiplex vary both by species and by disease, which likely reflects the type or location of GAGs that accumulate. Bones are severely shortened in mice and dogs with MPS VII [3-6], in which animals accumulate chondroitin-4sulfate (C4S), chondroitin-6-sulfate (C6S), heparan sulfate (HS), and dermatan sulfate (DS) due to deficiency of $\beta$-glucuronidase (GUSB; EC 3.2.1.31). Bones are also severely shortened in MPS VI [7], which is due to $N$-acetylgalactosamine 4-sulfatase (EC 3.1.6.12) deficiency, an enzyme that contributes to the degradation of C4S and DS. Bone disease is mild in MPS I mice and dogs [6,8-10] and in MPS II mice [11] that accumulate HS and DS due to deficiency of $\alpha$-L-iduronidase (IDUA, EC 3.2.1.76) and iduronate-2-sulfatase (EC 3.1.6.13), respectively. No bone defects have been reported in mice with MPS IIIA [12] or IIIB [13], which accumulate HS. The mildness of bone disease in mice with MPS IVA [14] contrasts with the severity of bone disease in humans with MPS IV [1], which may reflect the fact that mice synthesize much less C6S than humans [14]. Thus, of the available MPS mouse models, only those that are deficient in enzymes contributing to the degradation of $\mathrm{C} 4 \mathrm{~S}$ have markedly shortened long bones. Intriguingly, C4S is the major GAG in the growth plate [15], the cartilaginous region near the ends of long bones where longitudinal bone growth takes place via the process of endochondral ossification, suggesting a mechanistic link between C4S and MPS bone shortening.

Endochondral ossification is controlled by many different pathways, a large number of which are regulated by GAGs. These include the fibroblast growth factors (FGFs), bone morphogenetic proteins (BMPs), transforming growth factor- $\beta$ (TGF $\beta$ ), and the wingless-type (Wnt) signaling pathway [16]. FGFs are attractive candidates for involvement in MPS VII bone shortening because GAGs mediate the interaction of FGFs with their receptors [17].

Furthermore, constitutive activation of FGFR3 causes the most common form of human dwarfism, achondroplasia [18], and the skeletal phenotype of achondroplasia mouse models [19] is quite similar to that of MPS VII. Indeed, C4S, which is elevated in the MPS syndromes that have the greatest effect on bone length, can activate FGF signaling through some FGFRs [20].

The goal of this study was to examine the pathogenesis of short bones in MPS mice. MPS VII was used as an MPS model that accumulates C4S and has short bones, while MPS I was used as a model that does not accumulate $\mathrm{C} 4 \mathrm{~S}$ and has near-normal length bones. The role of FGFR3 in mediating short bones was evaluated by crossing MPS VII mice with FGFR3-deficient mice. In addition, the effect of MPS VII on other signal transduction pathways known to regulate growth plate function was examined.

\section{MATERIALS AND METHODS}

All reagents were obtained from Sigma-Aldrich, St. Louis, MO, unless otherwise indicated. 


\section{Statistics}

Statistics were performed using Sigma Stat 3.1 (Systat Software, Chicago, IL). For comparing two groups, the Student's t test was used. For comparing more than two groups, one-way ANOVA with Tukey all-pairwise post-hoc analysis was used. All errors are reported as standard error of the mean (SEM).

Mice

MPS I mice and FGFR3-deficient mice were from a C57BL/6 background [10], while MPS VII mice were from a B6. C-H-2 ${ }^{\mathrm{bm} 1} / \mathrm{ByBir}$ background, a minor C57BL/6 variant [6]. Heterozygous mice from both backgrounds were maintained as controls, as these mice are physiologically normal. Since bone lengths were identical in normal mice from both the MPS I and MPS VII colonies, data from heterozygote normals of both groups were pooled in some experiments and are hereafter referred to as "normal." Additional mouse and genotyping information can be found in the supplemental methods.

\section{Radiographs}

Mice were sacrificed via $\mathrm{CO}_{2}$ inhalation, and legs, arms, and vertebral columns were excised and excess skin and tissue were removed. Radiographs were taken using a MX-20 Specimen Radiography System (Faxitron, Lincolnshire, IL) at $20 \mathrm{KV}$ for 15 seconds.

\section{Histology}

One day old mice were injected intraperitoneally (IP) with $100 \mathrm{mg}$ bromodeoxyuridine (BRDU)/kg body mass in $100 \mu \mathrm{l}$ of phosphate buffered saline (PBS; Invitrogen, Carlsbad, CA) 1 hour before sacrifice. Three week old mice were injected IP with $100 \mathrm{mg}$ BRDU/kg in 200 $\mu \mathrm{l}$ PBS 3 hours prior to sacrifice. Tibias were cleaned of excess skin and muscle, fixed overnight in Bouin's fixative, decalcified for 5 days in $10 \%$ formic acid, and embedded in paraffin. Six $\mu \mathrm{m}$ sections were stained with hematoxylin and eosin (H \& E), or processed for BRDU staining using a Zymed BRDU-Staining Kit (Invitrogen) per the manufacturer's instructions, except the trypsin digest for antigen retrieval was reduced to 5 minutes due to tissue loss with longer incubations.

\section{Immunohistochemistry}

GAGs in the growth plate were visualized by using antibodies specific for disaccharides left behind by enzymatic digestion [21]. Tibias from 3 week old mice were fixed in Bouin's solution and decalcified for 5 days with $10 \%$ formic acid, and sections were deparaffinized in xylene, then rehydrated through a gradient of ethanol and PBS. Sections were then incubated for 3 hours at $37^{\circ} \mathrm{C}$ with a GAG digestive enzyme. To detect chondroitin sulfate, the solution contained $0.5 \mathrm{U} / \mathrm{ml}$ chondroitinase AC-I (Seikagaku, Tokyo, Japan), $0.5 \mathrm{M}$ Tris- $\mathrm{HCl}$ at $\mathrm{pH}$ 8.0, and $0.1 \%$ bovine serum albumin (BSA; Invitrogen). Other sections were incubated in PBS as controls. Further washes, antibody incubations, and color reactions were done using a Vector M.O.M. Immunodetection Kit (Vector Labs, Burlingame, CA) according to the manufacturer's instructions. Sections digested with a chondroitinase or PBS were incubated with $10 \mu \mathrm{g} / \mathrm{ml}$ $\triangle \mathrm{Di}$-4S 2B6 (detects 4-sulfated disaccharides) antibody (Seikagaku).

Phosphorylation of signaling molecules was visualized using immunohistochemistry on 3 week old mouse tibias. Tibias were decalcified in 14\% EDTA for 2 days without prior fixation and then frozen in OCT embedding medium. Twelve $\mu \mathrm{m}$ sections were placed on Snowcoat $\mathrm{X}$-tra slides (Surgipath, Richmond, IL). Frozen slides were warmed to room temperature for 10 minutes and fixed with fresh $4 \%$ paraformaldehyde in PBS for 10 minutes at $4^{\circ} \mathrm{C}$. Sections were washed 3 times with $0.1 \%$ Tween-20 in PBS, endogenous peroxidase activity was inhibited with a 20 minute incubation in $0.6 \%$ hydrogen peroxide in $\mathrm{PBS}$ at $4^{\circ} \mathrm{C}$, and sections 
were washed again. Sections were blocked with $10 \%$ normal goat serum in PBS for 30 minutes at room temperature, then incubated overnight at $4^{\circ} \mathrm{C}$ with the primary antibody at 1:100 dilution in blocking buffer. Rabbit antibodies that recognize phosphorylated forms (designated by "p" here) from Cell Signaling Technology included antibodies for pSTAT1-ser727 (\#9177), pSTAT1-tyr701 (\#9167), pSTAT3-ser727 (\#9134), pSTAT3-tyr705 (\#9131), pSTAT5-tyr694 (\#9131), total STAT3 (\#9132), pSMAD1-ser463/465 (also recognizes SMAD5 and SMAD8 phosphorylated at homologous residues; \#9511), pSMAD2-ser465/467 (\#3101), p44/42 MAPK-thr202/tyr204 (\#9101S), p38 MAPK-thr180/tyr182 (\#9211S), pJAK1-tyr1022/1023 (\#3331), pJAK2-tyr1007/1008 (\#3771S), pTYK2-tyr1054/1055, and antibody \#3821, which recognizes the p85 PI3K binding motif (any pYXXM amino acid sequence). Following antibody incubation, sections were washed, incubated in biotinylated anti-rabbit IgG (Vector Labs) at 1:200 dilution in blocking buffer for 30 minutes at room temperature, processed with a Vectastain ABC Kit (Vector Labs), and developed with 3,3'-diaminobenzidine according to the manufacturer's instructions, which results in a brown color. A hamster antibody for total STAT1 (ATO-1D6) was generously provided by Robert Schreiber, and processed using hamster-specific reagents.

For detection of $\beta$-catenin, frozen sections of 3 week tibias were fixed in $10 \%$ formalin for 10 minutes at $4^{\circ} \mathrm{C}$, rinsed in PBS, then endogenous peroxidase activity was quenched in $3 \%$ hydrogen peroxide in methanol for 15 minutes. Slides were then washed in PBS, and incubated overnight at $4^{\circ} \mathrm{C}$ with anti- $\beta$-catenin (Santa Cruz Biotechnology) at a 1:250 dilution in 5\% normal goat serum diluted in PBS. Sections were washed, then incubated with biotinylated anti-goat IgG (Jackson ImmunoResearch Laboratory, West Grove, PA), after which development was performed as with STATs. Apoptosis was detected using a terminal deoxynucleotidyl transferase dUTP nick end labeling (TUNEL) assay performed on frozen 3 week mouse tibia sections with an in-situ cell death detection kit, POD (Roche Applied Science, Indianapolis, IN; \#11684817910) according to the manufacturer's instructions.

\section{Real-time PCR}

The proximal $4 \mathrm{~mm}$ of 3 week old mouse tibias (included the articular cartilage, epiphysis, and growth plate) was frozen in liquid nitrogen and pulverized using a mikro-dismembrator (Braun Biotech International, Allentown, PA), after which the RNA was suspended in Trizol (Invitrogen) and purified with an RNeasy Mini kit (Qiagen, Germantown, MD). cDNA was made from $1 \mu \mathrm{g}$ of RNA using superscript III reverse transcriptase and oligo dT (Invitrogen) in a total volume of $20 \mu \mathrm{L}$, which was diluted to a final volume of $70 \mu \mathrm{L}$ after reverse transcription, and real-time PCR was performed using $1 \mu \mathrm{L}$ of this cDNA in SYBR green master mix (SA Biosciences, Frederick, MD) on a 7500 Fast real-time machine (Applied Biosystems, Foster City, CA), according to the manufacturer's instructions. Primers used and calculations performed are described in supplemental methods.

\section{RNA in-situ hybridization}

RNA in-situ hybridizations were performed on mouse tibias using probes for collagen $\mathrm{X}$ (Col X) [22], collagen II (Col II) [23], and indian hedgehog (IHH) [24]. Tibias from 3 week-old mice were fixed in $10 \%$ formalin overnight, decalcified for 5 days in $10 \%$ formic acid, and sectioned in paraffin as above. Probes were ${ }^{35} \mathrm{~S}$ labeled and hybridized as previously described [25], then slides were placed in emulsion for 5 days. Developed slides were photographed in both bright field and dark field using identical settings for all sections of each probe. The signal seen on the dark field photographs was captured using Photoshop software (Adobe, San Jose, CA) and converted to a false color red, after which it was overlaid on the original bright field image. This allows for simultaneous perception of the signal (which can usually only be seen in a dark field image) and visualization of the tissue itself (better seen in bright field). 


\section{RESULTS}

\section{Long bone lengths}

Radiographs were taken at 3 and 6 weeks to determine the age at which bone defects develop in MPS mice. At 6 weeks, MPS VII bones were severely shortened, as MPS VII femurs, tibia, humeri, lumbar vertebrae, and caudal vertebrae were only $76 \pm 0.3 \%, 76 \pm 0.3 \%, 68 \pm 0.6 \%, 84$ $\pm 2.4 \%$, and $74 \pm 2.4 \%$ of normal respectively (Fig. $1 ; \mathrm{p}<0.01$ for all vs. normal). In contrast, although MPS I bones were slightly shortened, there were no statistically significant changes in any MPS I bone length except femurs, which were marginally shortened at $95 \pm 1.4 \%$ of normal ( $\mathrm{p}<0.01$ vs. normal). At 3 weeks, all measured bones in MPS VII mice were shortened, as femurs, tibias, humeri, lumbar vertebrae, and caudal vertebrae were only $78 \pm 1.3 \%, 81$ $\pm 1.9 \%, 84 \pm 1.6 \%, 81 \pm 3.2 \%$, and $67 \pm 2.3 \%$ of normal respectively (Fig. $1 ; \mathrm{p}<0.01$ for all vs. normal). Since few bone abnormalities were seen in MPS I mice at 6 weeks, they were not evaluated at 3 weeks. This demonstrates that bone disease is more severe in MPS VII than MPS I. Since MPS VII bone defects were readily apparent at 3 weeks, yet growth was still occurring, this age was chosen for further study to examine the mechanism of bone shortening.

\section{Characterization of growth plate}

One day old tibia sections showed no differences in growth plate morphology between normal, MPS I, and MPS VII mice (data not shown). However, 3 week-old tibias had disorganized growth plates and a marked decrease in the number of cells per column in the proliferating zone of MPS VII mice (12.8 \pm 0.9 cells/column) when compared to normal mice $(21.6 \pm 0.2$ cells/ column; $\mathrm{p}<0.01$ for MPS VII vs. normal), while MPS I mice were not significantly different from normal (20.5 \pm 0.9 cells/column; Figs. $2 \mathrm{~A}, 2 \mathrm{C})$. All groups had about 5 cells/column in the hypertrophic zone. Despite the decrease in the number of cells in the proliferating zone for the MPS VII mice, the thickness of the growth plate was about $1.3 \mathrm{~mm}$ in all mice, probably due to the increased size and spacing of the chondrocytes caused by GAG storage.

To measure the rates of proliferation in growth plates, tibias were stained for BRDU incorporation into DNA at ages of 1 day and 3 weeks. Staining revealed no differences in proliferation at 1 day of age (data not shown). At 3 weeks, MPS VII mice had rates that were significantly reduced in the proliferating zone when compared to normal mice, while MPS I mice retained relatively normal rates of proliferation (Figs. 2B, 2D). Staining for activated caspase 3, a marker for apoptosis, was not detected in the proliferating zone of either normal or MPS VII growth plates (data not shown). Apoptosis was also evaluated with a TUNEL assay, which showed few positive cells and no significant differences between normal and MPS VII growth plates (Table 1). Therefore, the reduced number of cells in the proliferating zone of MPS VII mice is probably due to decreased proliferation, which likely contributes to MPS VII bone shortening.

\section{Growth plate GAG accumulation}

Immunohistochemistry for a variety of GAGs was performed on the growth plates of tibias at 3 weeks. This experiment makes use of endoglycosidases that digest GAG chains until only a disaccharide remains, creating a double bond on the terminal sugar. Incubation with an antibody that recognizes the modified disaccharide allows visualization of the GAG in the tissue. Staining showed little background with controls whose GAGs were not digested (Supplemental Fig. 1). Digestion with chondroitinase AC-I followed by $\triangle \mathrm{Di}-4 \mathrm{~S}$ antibody revealed low levels of $\mathrm{C} 4 \mathrm{~S}$ in normal growth plates, a modest increase in MPS I and a dramatically elevated amount in MPS VII (Fig. 3). Chondroitinase B digests followed by $\Delta$ di-4S antibody showed a slight elevation in DS accumulation in MPS I and MPS VII mice, while HS accumulation was low in all growth plates (Supplemental Fig. 1). These results 
suggest that $\mathrm{C} 4 \mathrm{~S}$ accumulation in the growth plate is the most likely candidate GAG for involvement in shortened bones in MPS VII.

\section{Role of FGFR3}

Due to the similarities in growth plates and bone lengths between achondroplasia and MPS VII, as well as the fact that C4S can activate FGFR2 [20] and FGFR3 [JAM, KPP, unpublished data] in vitro, we hypothesized that MPS VII bone shortening could be due to overactivation of FGFR3, indicating that FGFR3 deficiency might restore MPS VII mouse bones to normal length. We therefore set up breeding between FGFR3-deficient and MPS VII mice (referred to here as MPS VII -/-) in order to obtain double mutants. However, MPS VII -/- FGFR3 -/mice tibias were not significantly different from MPS VII -/- FGFR3 +/- mice (Fig. 4).

Additionally, MPS VII -/- FGFR3 -/- mouse growth plates were disorganized and had reduced numbers of chondrocytes, resembling MPS VII mouse growth plates (data not shown). These data suggest that FGFR3 is not critical for MPS VII bone shortening.

\section{STAT Immunohistochemistry}

STAT1 is anti-proliferative in the growth plate [26], while STAT3 is pro-proliferative [27, 28]. STAT1 and STAT3 are activated primarily by phosphorylation [29]. Tyrosine phosphorylation is necessary for dimerization and translocation to the nucleus, while serine phosphorylation is necessary for maximal transcription [29]. Therefore, to ascertain whether the activation of either STAT protein was affected in MPS VII growth plates, immunohistochemistry for a variety of STATs phosphorylated at residues critical for their activity was performed on 3 week-old tibia sections. Most stains were performed on frozen sections, as paraffin sections lost immunoreactivity for most antibodies. In all cases, staining of the bone marrow was positive, and was used to confirm that the staining was effective. Immunohistochemistry was also performed using antibodies for total STAT1 and total STAT3, with no significant differences between the normal and MPS VII animals (Table 1). Staining for pSTAT5-tyr694 was not detected in the growth plate in either normal or MPS VII mice at this age (Table 1).

Staining showed a 4-fold increase in the number of cells positive for pSTAT1-ser727 in MPS VII mice as compared to normal mice (Fig. 5A, Table 1). Although morphology was poor in these frozen sections, the pSTAT1-ser727 antibody was effective on paraffin-embedded sections, and the improved morphology confirmed nuclear staining (Supplemental Fig. 2A). Staining for the pSTAT1-tyr701 antibody was only weakly positive in all mice (Supplemental Fig. 2B, Table 1).

Staining for the pro-proliferative STAT3 showed that the number of cells positive for pSTAT3tyr705 was markedly decreased to about $40 \%$ of normal in MPS VII growth plates (Fig. 5B, Table 1). STAT3 phosphorylated at ser727, on the other hand, was modestly increased in MPS VII mice (Supplemental Fig. 2C, Table 1). Staining for each phospho-STAT was also performed on MPS I sections, and was found to be similar to normal mice in each case (Table 1). Based on these data, we hypothesized that either increased activity of the anti-proliferative STAT1 or decreased activity of the pro-proliferative STAT3 could be responsible for the growth plate proliferation defect in MPS VII mice.

\section{Immunohistochemistry of STAT kinases}

Tyrosine phosphorylation in STATs can be performed by Janus kinases (JAK1 and JAK2) and tyrosine kinase 2 (TYK2) [29]. In order to evaluate these potential regulators of STAT3 phosphorylation at tyrosine705, immunohistochemistry was also performed for these kinases. This revealed a marked reduction in the amount of pTYK2-tyr1054/1055 in MPS VII growth plates as compared to normal (Fig. 5C,Table 1). There was also a reduction in the amount of 
pJAK1-tyr1022/1023 and pJAK2-tyr1007/1008 in the MPS VII growth plate as compared to the normal growth plate (Table 1,Supplemental Figs. 2D, 2E). We also examined the phosphoinositide 3-kinase binding motif (PI3K-bm), a motif common to several tyrosine kinases that are able to bind PI3K upon phosphorylation, including TYK2 [30], which was also markedly decreased in MPS VII growth plates as compared to normal growth plates (Fig. 5D, Table 1).

\section{Real-time PCR for growth plate genes and STAT regulators}

Growth plate RNA was evaluated to determine if genes important for chondrocyte development and the STAT pathway were affected by MPS VII. Since it was not practical to purify only the growth plate from mice, real-time reverse transcriptase (RT)-PCR was performed on RNA isolated from the proximal $4 \mathrm{~mm}$ of tibia, a region which includes the growth plate $(\sim 1 \mathrm{~mm})$, the epiphysis, and the articular cartilage. RNA in-situ hybridizations for select genes were used to confirm that real-time results reflected actual growth plate RNA levels.

Collagen X (ColX) is expressed in hypertrophic chondrocytes and was unchanged in MPS VII mice in real-time RT-PCR (Fig. 6) and in in-situ hybridizations (Figs. 7A, 6D), which is consistent with the fact that the number of hypertrophic chondrocytes was unchanged (Fig. 2C). Real-time RT-PCR showed that MPS VII growth plates appeared to have a slight, but not significant decrease in the level of collagen II (Col II), which is expressed in chondrocytes in the proliferating zone, to $40.3 \pm 18.2 \%$ of normal (Fig. 6), and a similar decrease was seen in the in-situ hybridizations (Figs. 7B, 7E). Indian hedgehog (IHH), which is expressed in early hypertrophic chondrocytes and is involved in regulating chondrocyte proliferation and differentiation [16], was reduced to $33.8 \pm 13.1 \%$ of normal ( $\mathrm{p}=0.025 \mathrm{vs}$. normal) in real-time RT-PCR (Fig. 6), and was also reduced in the in-situ hybridizations to a similar extent (Figs. 7C, 7F). Thus, real-time PCR results were in good agreement with in-situ hybridization results and suggests that those data accurately reflect growth plate gene expression.

Expression of potential regulators of bone growth are shown in Fig. 6, several of which are significantly reduced in MPS VII mice. Parathyroid hormone related peptide receptor (PTHrPR), which plays a role in local growth plate regulation, and insulin-like growth factor 1 (IGF1), which is a downstream target of growth hormone in growth plate chondrocytes during post-natal development [16], had no significant changes in expression in MPS VII growth plates. However, receptor activator for nuclear factor $\mathrm{\kappa B}$ ligand (RANKL) and osteoprotegerin (OPG) expression were moderately reduced in MPS VII mice $(34.8 \pm 7.8 \%$, and $31.4 \pm 8.8 \%$ of normal respectively; $\mathrm{p}<0.05$ for both). RANKL and OPG are involved in regulation of osteoclasts [31]. Matrix metallopeptidase 13 (MMP13, also known as collagenase 3), which is expressed at the chondro-osseous junctions of the secondary center of ossification and the growth plate [32], was markedly reduced in MPS VII mice $(18.1 \pm 3.3 \%$ of normal, $\mathrm{p}=0.001)$. MMP3, which is a protease upregulated in MPS I aortas33 [33], was increased to $462 \pm 96.2 \%$ of normal ( $\mathrm{p}=0.008)$, while cathepsin $\mathrm{S}(\mathrm{CathS})$, another protease that is upregulated in MPS I aorta, was slightly, but not significantly elevated at 1.8 fold normal.

The activity of tyrosine kinases that phosphorylate STATs can be induced by several cytokines. Members of the interleukin 6 (IL6) family, such as IL6, oncostatin M (OSM), and leukemia inhibitory factor (LIF) are canonical stimulators of STAT3 phosphorylation, while interferon $\gamma($ IFN $\gamma$ ) and interleukin $1 \beta$ (IL1 $\beta$ ) classically stimulate STAT1. STAT phosphorylation can be inhibited by numerous phosphatases, such as SH-domain containing phosphatase 1 (SHP1) and SHP2, and protein tyrosine phosphatase - receptor type C (PTPRC). STAT activity can also be repressed by suppressor of cytokine signaling 1 (SOCS1), SOCS2, and SOCS3, and protein inhibitor of activated STAT1 (PIAS1) and PIAS3 [29]. Interestingly, the SOCS family members participate in a negative feedback loop and are upregulated in response to increased STAT3, LIF, or IL6 [34,35]. 
Several IL6 family members were markedly downregulated in MPS VII tibias, including LIF (19.2 $\pm 3.7 \%$ of normal, $\mathrm{p}=0.035)$, OSM $(9.3 \pm 3.4 \%$ of normal, $\mathrm{p}=0.027)$, cardiotrophin 1 (CTF1; 43.4 $\pm 7.1 \%$ of normal, $\mathrm{p}=0.017$ ), and cardiotrophin-like cytokine factor 1 (CLCF1; 16.3 $\pm 4.2 \%$ of normal, $\mathrm{p}=0.005$ ), while IL6, IL11, and ciliary neurotrophic factor (CNTF) were not significantly changed (Fig. 6). In MPS VII mice, IFN $\gamma$ and IL1 $\beta$, which induce STAT1 tyrosine phosphorylation, were reduced to $32.8 \pm 7.5 \%$ of normal $(\mathrm{p}=0.016)$ and $27.2 \pm 7.5 \%$ of normal $(\mathrm{p}=0.011)$, respectively, while several proteins involved in the tumor necrosis factor $\alpha$ $(\mathrm{TNF} \alpha)$ pathway were also modestly reduced, including tumor necrosis factor ligand superfamily member 10 (TNFSF $10 ; 41.7 \pm 10.4 \%$ normal, $\mathrm{p}=0.001$ ), and tumor necrosis factor receptor-associated factor 6 (TRAF6; $38.7 \pm 8.8 \%$ normal, $\mathrm{p}=0.001$ ), although TNF $\alpha$ itself was not significantly reduced (Fig. 6). Of the negative regulators of STAT signaling, SHP1, SHP2, and each member of the SOCS family members examined were decreased to between 33-46\% of normal in MPS VII mice (Fig. 6; $\mathrm{p}<0.05$ for all), suggesting that the growth plate is responding to a decrease in STAT3 activity but these pathways are probably not responsible for its loss of phosphorylation. These data are consistent with the hypothesis that reduced levels of IL6 family cytokines are responsible for reduced STAT3 tyrosine phosphorylation.

\section{Additional signal transduction pathways}

Immunohistochemistry for markers of several other signal transduction pathways were performed as summarized in Table 1. Staining for $\beta$-catenin (downstream of Wnt) and pSMAD2 (downstream of TGF $\beta$ ) was very low in the growth plate for both normal and MPS VII mice. Staining for pSMAD1,5,8 (downstream of BMP) was strong in growth plates from both normal and MPS VII, and there was no perceivable differences in the two. MPS I growth plates were also stained with both phospho-SMAD antibodies, but were not different from either normal or MPS VII growth plates.

\section{DISCUSSION}

\section{Progression of bone defects}

The goal of this study was to understand the pathogenesis of short bones in MPS VII. Three weeks was chosen as the time point for our investigations, as bones were clearly abnormal in MPS VII mice at that age, with tibias at only $81 \%$ of normal length (Fig. 1). However, growth is still actively occurring, as bones were only about $85 \%$ of their adult length, making this age ideal for these studies.

\section{MPS VII growth plates have reduced proliferation}

MPS VII growth plates had a marked decrease in the number of cells in the proliferating zone of the growth plate to $60 \%$ of normal, which appears to be due to reduced chondrocyte proliferation to 55\% of normal (Fig. 2). MPS I growth plates on the other hand, had normal chondrocyte proliferation, which is consistent with their near-normal length bones (Figs. 1, 2). There appeared to be no increase in apoptosis in MPS VII growth plates as assessed by staining for activated caspase 3 and TUNEL assay (data not shown; Table 1). These results suggest that MPS VII bone shortening is due to decreased growth plate chondrocyte proliferation, and that fewer chondrocytes in the growth plate results in less ossification and shorter bones.

\section{Importance of $\mathrm{C} 4 \mathrm{~S}$ accumulation to bone shortening}

Immunohistochemistry showed that C4S accumulated at very high levels in MPS VII growth plates as compared to normal, but was only slightly elevated in MPS I (Fig. 3), and that other GAGs were present at relatively low levels (Supplemental Fig. 1). There was a significant amount of staining for $\mathrm{C} 4 \mathrm{~S}$ in the extracellular matrix directly surrounding individual cells, making C4S ideally positioned to influence the activity of a cell membrane receptor that could 
affect bone growth. Indeed, comparisons of the available mouse models of MPS (see introduction) reveals that only the two that are the result of deficiency in enzymes that contribute to degradation of C4S, MPS VI [7] and MPS VII [3-5], have severely shortened bones. This suggests that C4S could be important mechanistically in MPS bone shortening. Furthermore, deletion of the chondroitin-4-sulfotransferase 1 gene, which encodes an enzyme that adds the sulfate group to the 4-O-position of chondroitin, results in increased proliferation in growth plate chondrocytes [36], suggesting that accumulation of $\mathrm{C} 4 \mathrm{~S}$ may reduce chondrocyte proliferation.

\section{FGFR3 and other signal transduction pathways}

Deficiency of FGFR3 did not prevent short bones in MPS VII mice (Fig. 4), strongly suggesting that FGFR3 does not mediate MPS VII bone disease. Immunohistochemistry for pSMAD2, pSMAD1,5,8, and $\beta$-catenin were all unchanged between normal and MPS VII sections (Table 1), suggesting that the TGF $\beta$, BMP, and Wnt pathways, respectively, are also probably not key mediators of MPS VII bone shortening.

\section{STAT phosphorylation}

STATs are a group of transcription factors that are selectively activated by numerous cytokines (such as the IL6 family) and by growth factors (such as FGF). STATs are of particular interest in MPS, as recent data indicates that aortic disease in MPS may be mediated through STATs [33]. STAT1 is thought to have an anti-proliferative effect on growth plate chondrocytes [26], while STAT3 is believed to be pro-proliferative in the growth plate [27,28]. STAT activity is largely controlled by serine and tyrosine phosphorylation. Tyrosine phosphorylation is performed by a number of kinases, including TYK2, JAK1, and JAK2 [29,37], which in turn can be activated by cytokines such as LIF and other IL6 family members $[38,39,44]$. LIF is constitutively expressed in growth plate chondrocytes [40] and osteoblasts [41], but is expressed at a low level in articular cartilage [42] and in bone marrow [43]. LIF is a member of the IL6 family of cytokines, which also includes IL6, IL11, OSM, CNTF, CTF1, and CLCF1. All IL6 family cytokines signal through a receptor complex containing glycoprotein 130 (gp130) associated with another receptor [44]. In the case of LIF, this complex is a heterodimer of gp130 and LIF receptor $\beta$ (LIFR $\beta$ ) [44]. This complex can directly phosphorylate STAT3 at tyrosine 705 , in addition to activating JAK1, JAK2, and TYK2 $[39,44]$. Mutations in the gp130 domain responsible for STAT3 phosphorylation [27] and loss of function mutations in LIFR $\beta$ [45] both result in shortened bones in mice, while LIF-deficiency results in retarded post-natal growth [46]. However, deficiency of IL6 and/or the IL11 receptor does not affect bone length [47], and deficiency of CNTF, CTF1, OSM, or the OSM receptor does not result in any overt bone abnormalities [48-51; personal correspondence: Hans Thoenen, Max Planck Institute of Neurobiology, Martinsried, Germany; Klaus Unsicker, University of Heidelberg, Heidelberg, Germany; Atsushi Miyajima, University of Tokyo, Tokyo, Japan]. These genetic data strongly suggest that LIF is the most likely IL6 family member to promote bone elongation through STAT3 signaling.

In MPS VII growth plates, the pro-proliferative STAT3 has markedly reduced phosphorylation at tyrosine705 as compared to normal (Fig. 5B, Table 1). Kinases that perform this phosphorylation also had reduced phosphorylation in MPS VII growth plates, including pTYK2-tyr1054/1055 (Fig. 5C), pJAK1-tyr1022/1023, and pJAK2-tyr1007/1008

(Supplemental Fig. 2), while immunohistochemistry for the PI3K binding motif present in these and other kinases was also reduced in MPS VII growth plates (Fig. 5D). These changes in kinase and STAT3 phosphorylation may be due to a reduction in the RNA expression of LIF, OSM, and several other IL6 family cytokines in MPS VII samples (Fig. 6). The reduction of LIF RNA was likely due to reduced expression in the growth plate, as LIF is expressed in the hypertrophic zone but not in bone marrow [43], although attempts to localize LIF in tibia 
sections using immunohistochemistry were unsuccessful. Expression of IHH, which is important for growth plate proliferation and differentiation and for bone elongation, is reduced in LIF-deficient mice, but is increased when LIF is injected [52]. Thus, the reduction in IHH expression in MPS VII growth plates (Fig. 6) may be due to the reduction in LIF expression. In addition, RANKL and OPG expression is stimulated by LIF [53], which is consistent with the fact that both genes have reduced expression in MPS VII growth plates (Fig. 6). Although STAT3 tyrosine phosphorylation and/or transcriptional activity can also be negatively regulated by phosphatases [54], SOCS [34], and PIAS3 [29], real-time RT-PCR showed that these genes were either unchanged or downregulated in MPS VII tibias (Fig. 6), suggesting that they are responding to a decrease in STAT3 activity as part of a feedback loop, rather than actually causing that decrease. We propose that reduced tyrosine701 phosphorylation of STAT3 is caused by a reduction in expression of LIF and related family members and may be responsible for reduced proliferation of chondrocytes in the proliferating zone, contributing to shortened bones in MPS VII mice.

STAT1 is an anti-proliferative transcription factor. STAT1 phosphorylation at serine 727 was strikingly increased in MPS VII growth plates as compared to normal (Fig. 5A). Although classically STAT1 is thought to require phosphorylation of tyrosine 701 for nuclear translocation and transcriptional activity, STAT1 that is phosphorylated at serine 727 in the absence of tyrosine phosphorylation retains some DNA binding and transcriptional activity [55]. Staining for pSTAT1-tyr701 was weak in the growth plates of both normal and MPS VII mice, but STAT1 that was phosphorylated at serine 727 was clearly nuclear (Supplemental Fig. 2A). It has been proposed that GAG accumulation in MPS activates toll-like receptor 4 [56], which stimulates serine phosphorylation of STAT1 [57], and STAT1 is also important in mediating achondroplastic dwarfism in FGFR3 overactivating mutations [19]. These data suggest that increased phosphorylation of STAT1 at serine 727 might also play a role in MPS VII bone shortening by reducing chondrocyte proliferation in the growth plate.

\section{Conclusion}

The results of this study suggest that accumulation of C4S in MPS VII growth plates results in a reduction of chondrocyte proliferation and cell number in the growth plate, and is likely responsible for the shortened long bones. This was associated with reduced levels of tyrosinephosphorylated STAT3, which may reflect the reduced phosphorylation of TYK2, JAK1, and JAK2 in MPS VII growth plates. RNA expression of LIF, which activates STAT3 and other members of the JAK/STAT pathway and is necessary for bone elongation, was reduced to $19 \%$ of normal in the growth plate of the MPS VII mice. We propose that reduction in expression of LIF is responsible for reduced activation of STAT3, leading to reduced proliferation and shortened bones, although increased serine phosphorylation of STAT1 and other mechanisms are feasible. It remains unclear as to what mechanism is responsible for reduced levels of LIF in the growth plate, which is currently being investigated.

\section{Supplementary Material}

Refer to Web version on PubMed Central for supplementary material.

\section{Acknowledgments}

We thank David Ornitz for providing the FGFR3-deficient mice and for help with bone homogenization, Monica Bessler for use of a real-time PCR machine, Doug Tollefsen and Tusar Giri for help with GAG immunohistochemistry, Bill Coleman and Marlene Scott for advice with bone histology, Matthew Silva for access to his radiograph machine, and Robert Schreiber and Kathleen Sheehan for an anti-STAT1 antibody. 


\section{References}

1. Neufeld, EF.; Meunzer, J. The mucopolysaccharidoses. In: Scriver, CR.; Beaudet, AL.; Sly, WS.; Valle, D., editors. Metabolic and Molecular Basis of Inherited Disease. McGraw-Hill; New York: 2001. p. 3421-3452.

2. Pastores GM, Arn P, Beck M, Clarke JTR, Guffon N, Kaplan P, Muenzer J, Norato DYJ, Shapiro E, Thomas J, Viskochil D, Wraith JE. The MPS I registry: design, methodology, and early findings of a global disease registry for monitoring patients with Mucopolysaccharidosis Type I. Mol Genet Metab 2007;91:37-47. [PubMed: 17336562]

3. Mango RL, Xu L, Sands MS, Vogler C, Seiler G, Schwartz T, Haskins ME, Ponder KP. Neonatal retroviral vector-mediated hepatic gene therapy reduces bone, joint, and cartilage disease in mucopolysaccharidosis VII mice and dogs. Mol Gen Metab 2004;82:4-19.

4. Vogler C, Birkenmeier EH, Sly WS, Levy B, Pegors C, Kyle JW, Beamer WG. A murine model of mucopolysaccharidosis VII. Gross and microscopic findings in beta-glucuronidase-deficient mice. Am J Pathol 1990;136:207-217. [PubMed: 2105058]

5. Birkenmeier EH, Davisson MT, Beamer WG, Ganschow RE, Vogler CA, Gwynn B, Lyford KA, Maltais LM, Wawrzyniak CJ. Murine mucopolysaccharidosis type VII. Characterization of a mouse with beta-glucuronidase deficiency. J Clin Invest 1989;83:1258-1266. [PubMed: 2495302]

6. Herati RS, Knox VW, O’Donnell P, D’Angelo M, Haskins ME, Ponder KP. Radiographic evaluation of bones and joints in mucopolysaccharidosis I and VII dogs after neonatal gene therapy. Mol Genet Metab 2008;95:142-151. [PubMed: 18707908]

7. Evers M, Saftig P, Schmidt P, Hafner A, McLoghlin DB, Schmahl W, Hess B, von Figura K, Peters C. Targeted disruption of the arylsulfatase B gene results in mice resembling the phenotype of mucopolysaccharidosis VI. Proc Natl Acad Sci USA 1996;93:8214-8219. [PubMed: 8710849]

8. Clarke LA, Russell CS, Pownall S, Warrington CL, Borowski A, Dimmick JE, Toone J, Jirik FR. Murine mucopolysaccharidosis type I: targeted disruption of the murine alpha-L-iduronidase gene. Hum Mol Genet 1997;6:503-511. [PubMed: 9097952]

9. Liu Y, Xu L, Hennig AK, Kovacs A, Fu A, Chung S, Lee D, Wang B, Herati RS, Ogilvie JM, Cai S, Ponder KP. Liver-directed neonatal gene therapy prevents cardiac, bone, ear, and eye disease in mucopolysaccharidosis I mice. Mol Ther 2005;11:35-47. [PubMed: 15585404]

10. Ohmi K, Greenberg DS, Rajavel KS, Ryazantsev S, Li HH, Neufeld EF. Activated microglia in cortex of mouse models of mucopolysaccharidoses I and IIIB. Proc Natl Acad Sci USA 2003;100:19021907. [PubMed: 12576554]

11. Garcia AR, Pan J, Lamsa JC, Muenzer J. The characterization of a murine model of mucopolysaccharidosis II (Hunter syndrome). J Inherit Metab Dis 2007;30:924-934. [PubMed: 17876721]

12. Bhaumik M, Mulle VJ, Rozaklis T, Johnson L, Dobrenis K, Bhattacharyya R, Wurzelmann S, Finamore P, Hopwood JJ, Walkley SU, Stanley P. A mouse model for mucopolysaccharidosis type III A (Sanfilippo syndrome). Glycobiology 1999;9:1389-1396. [PubMed: 10561464]

13. Li HH, Yu WH, Rozengurt N, Zhao HZ, Lyons KM, Anagnostaras S, Fanselow MS, Suzuki K, Vanier MT, Neufeld EF. Mouse model of Sanfilippo syndrome type B produced by targeted disruption of the gene encoding alpha-N-acetylglucosaminidase. Proc Natl Acad Sci USA 1999;96:14505-14510. [PubMed: 10588735]

14. Tomatsu S, Vogler C, Montaño AM, Gutierrez M, Oikawa H, Dung VC, Orii T, Noguchi A, Sly WS. Murine model (Galns(tm(C76S)slu)) of MPS IVA with missense mutation at the active site cysteine conserved among sulfatase proteins. Mol Genet Metab 2007;91:251-258. [PubMed: 17498992]

15. Byers A, Caterson B, Hopwood JJ, Foster BK. Immunolocation analysis of glycosaminoglycans in the human growth plate. J Histochem Cytochem 1992;40:275-282. [PubMed: 1372629]

16. van der Eerden BCJ, Karperien M, Wit JM. Systemic and local regulation of the growth plate. Endocr Rev 2003;24:782-801. [PubMed: 14671005]

17. Su N, Du X, Chen L. FGF signaling: its role in bone development and human skeleton diseases. Front Biosci 2008;13:2842-2865. [PubMed: 17981758] 
18. Wilkin, DJ.; Hecht, JT.; Francomano, CJ. Achondroplasia and pseudoachondroplasia. In: Scriver, CR.; Beaudet, AL.; Sly, WS.; Valle, D., editors. Metabolic and Molecular Basis of Inherited Disease. McGraw-Hill; New York: 2001. p. 5379-5395.

19. Chen L, Adar R, Yang X, Monsonego EO, Li C, Hauschka PV, Yayon A, Deng C. Gly369Cys mutation in mouse FGFR 3 causes achondroplasia by affecting both chondrogenesis and osteogenesis. J Clin Invest 1999;104:1517-1525. [PubMed: 10587515]

20. McDowell LM, Frazier BA, Studelska DR, Gilljum K, Chen J, Liu J, Yu K, Ornitz DM, Zhang L. Inhibition or activation of Apert Syndrome FGFR2 (S252W) signaling by specific glycosaminoglycans. J Biol Chem 2006;281:6924-6930. [PubMed: 16373332]

21. Giri TK, Tollefsen DM. Placental dermatan sulfate: isolation, anticoagulant activity, and association with heparin cofactor II. Blood 2006;107:2753-2758. [PubMed: 16339402]

22. Apte SS, Seldin MF, Hayashi M, Olsen BR. Cloning of the human and mouse type X collagen genes and mapping of the mouse type X collagen gene to chromosome 10. Eur J Biochem 1992;206:217224. [PubMed: 1587271]

23. Kohno K, Martin GR, Yamada Y. Isolation and characterization of a cDNA for the amino-terminal portion of the pro-alpha 1(II) chain of cartilage collagen. J Biol Chem 1984;259:13668-13673. [PubMed: 6094525]

24. Long F, Zhang XM, Karp S, Yang Y, McMahon AP. Genetic manipulation of hedgehog signaling in the endochondral skeleton reveals a direct role in the regulation of chondrocyte proliferation. Development 2001;128:5099-5108. [PubMed: 11748145]

25. Lee K, Lanske B, Karaplis AC, Deeds JD, Kohno H, Nissenson RA, Kronenberg HM, Segre GV. Parathyroid hormone-related peptide delays terminal differentiation of chondrocytes during endochondral bone development. Endocrinology 1996;137:5109-5118. [PubMed: 8895385]

26. Sahni M, Ambrosetti D, Mansukhani A, Gertner R, Levy D, Basilico C. FGF signaling inhibits chondrocyte proliferation and regulates bone development through the STAT-1 pathway. Genes Dev 1999;13:1361-1366. [PubMed: 10364154]

27. Sims NA, Jenkins BJ, Quinn JM, Nakamura A, Glatt M, Gillespie MT, Ernst M, Martin TJ. Glycoprotein 130 regulates bone turnover and bone size by distinct downstream signaling pathways. J Clin Invest 2004;113:379-389. [PubMed: 14755335]

28. Stephanou A, Latchman DS. Opposing actions of STAT-1 and STAT-3. Growth Factors 2005;23:177-182. [PubMed: 16243709]

29. Lim CP, Cao X. Structure, function, and regulation of STAT proteins. Mol Biosyst 2006;2:536-550. [PubMed: 17216035]

30. Rikova K, Guo A, Zeng Q, Possemato A, Yu J, Haack H, Nardone J, Lee K, Reeves C, Li Y, Hu Y, Tan Z, Stokes M, Sullivan L, Mitchell J, Wetzel R, Macneill J, Ren JM, Yuan J, Bakalarski CE, Villen J, Kornhauser JM, Smith B, Li D, Zhou X, Gygi SP, Gu TL, Polakiewicz RD, Rush J, Comb MJ. Global survey of phosphotyrosine signaling identifies oncogenic kinases in lung cancer. Cell 2007;131:1190-1203. [PubMed: 18083107]

31. Boyce BF, Xing L. Functions of RANKL/RANK/OPG in bone modeling and remodeling. Arch Biochem Biophys 2008;473:139-146. [PubMed: 18395508]

32. Alvarez J, Costales L, Serra R, Balbín M, López JM. Expression patterns of matrix metalloproteinases and vascular endothelial growth factor during epiphyseal ossification. J Bone Miner Res 2005;20:1011-1021. [PubMed: 15883642]

33. Ma X, Tittiger M, Knutsen RH, Kovacs A, Schaller L, Mecham RP, Ponder KP. Upregulation of elastase proteins results in aortic dilatation in mucopolysaccharidosis I mice. Mol Genet Metab 2008;94:298-304. [PubMed: 18479957]

34. Larsen L, Röpke C. Suppressors of cytokine signalling: SOCS. APMIS 2002;110:833-844. [PubMed: 12645661]

35. Naka T, Narazaki M, Hirata M, Matsumoto T, Minamoto S, Aono A, Nishimoto N, Kajita T, Taga T, Yoshizaki K, Akira S, Kishimoto T. Structure and function of a new STAT-induced STAT inhibitor. Nature 1997;387:924-929. [PubMed: 9202127]

36. Klüppel M, Wight TN, Chan C, Hinek A, Wrana JL. Maintenance of chondroitin sulfation balance by chondroitin-4-sulfotransferase 1 is required for chondrocyte development and growth factor signaling during cartilage morphogenesis. Development 2005;132:3989-4003. [PubMed: 16079159] 
37. Rani MR, Leaman DW, Han Y, Leung S, Croze E, Fish EN, Wolfman A, Ransohoff RM. Catalytically active TYK2 is essential for interferon-beta-mediated phosphorylation of STAT3 and interferonalpha receptor-1 (IFNAR-1) but not for activation of phosphoinositol 3-kinase. J Biol Chem 1999;274:32507-32511. [PubMed: 10542297]

38. Kodama H, Fukuda K, Pan J, Makino S, Baba A, Hori S, Ogawa S. Leukemia inhibitory factor, a potent cardiac hypertrophic cytokine, activates the JAK/STAT pathway in rat cardiomyocytes. Circ Res 1997;81:656-663. [PubMed: 9351438]

39. Ernst M, Oates A, Dunn AR. Gp130-mediated signal transduction in embryonic stem cells involves activation of Jak and Ras/mitogen-activated protein kinase pathways. J Biol Chem 1996;271:3013630143. [PubMed: 8939963]

40. Grimaud E, Blanchard F, Charrier C, Gouin F, Redini F, Heymann D. Leukaemia inhibitory factor (lif) is expressed in hypertrophic chondrocytes and vascular sprouts during osteogenesis. Cytokine 2002;20:224-230. [PubMed: 12550107]

41. Liu F, Aubin JE, Malaval L. Expression of leukemia inhibitory factor (LIF)/interleukin-6 family cytokines and receptors during in vitro osteogenesis: differential regulation by dexamethasone and LIF. Bone 2002;31:212-219. [PubMed: 12110437]

42. Sandell LJ, Xing X, Franz C, Davies S, Chang LW, Patra D. Exuberant expression of chemokine genes by adult human articular chondrocytes in response to IL-1beta. Osteoarthritis Cartilage 2008;16:1560-1571. [PubMed: 18565769]

43. Barton BE, Murphy TF. Constitutive expression of IL-6-LIKE cytokines in normal bone marrow: implications for pathophysiology of myeloma. Cytokine 2000;12:1537-1545. [PubMed: 11023670]

44. Heinrich PC, Behrmann I, Müller-Newen G, Schaper F, Graeve L. Interleukin-6-type cytokine signalling through the gp130/Jak/STAT pathway. Biochem J 1998;334:297-314. [PubMed: 9716487]

45. Ware CB, Horowitz MC, Renshaw BR, Hunt JS, Liggitt D, Koblar SA, Gliniak BC, McKenna HJ, Papayannopoulou T, Thoma B, Cheng L, Donovan PJ, Peschon JJ, Bartlett PF, Willis CR, Wright BD, Carpenter MK, Davison BL, Gearing DP. Targeted disruption of the low-affinity leukemia inhibitory factor receptor gene causes placental, skeletal, neural and metabolic defects and results in perinatal death. Development 1995;121:1283-1299. [PubMed: 7789261]

46. Stewart CL, Kaspar P, Brunet LJ, Bhatt H, Gadi I, Köntgen F, Abbondanzo SJ. Blastocyst implantation depends on maternal expression of leukaemia inhibitory factor. Nature 1992;359:76-79. [PubMed: 1522892]

47. Sims NA, Jenkins BJ, Nakamura A, Quinn JM, Li R, Gillespie MT, Ernst M, Robb L, Martin TJ. Interleukin-11 receptor signaling is required for normal bone remodeling. J Bone Miner Res 2005;20:1093-1102. [PubMed: 15940362]

48. Masu Y, Wolf E, Holtmann B, Sendtner M, Brem G, Thoenen H. Disruption of the CNTF gene results in motor neuron degeneration. Nature 1993;365:27-32. [PubMed: 8361533]

49. Oberle S, Schober A, Meyer V, Holtmann B, Henderson C, Sendtner M, Unsicker K. Loss of leukemia inhibitory factor receptor beta or cardiotrophin-1 causes similar deficits in preganglionic sympathetic neurons and adrenal medulla. J Neurosci 2006;26:1823-1832. [PubMed: 16467531]

50. Minehata K, Takeuchi M, Hirabayashi Y, Inoue T, Donovan PJ, Tanaka M, Miyajima A. Oncostatin $\mathrm{M}$ maintains the hematopoietic microenvironment and retains hematopoietic progenitors in the bone marrow. Int J Hematol 2006;84:319-327. [PubMed: 17118758]

51. Tanaka M, Hirabayashi Y, Sekiguchi T, Inoue T, Katsuki M, Miyajima A. Targeted disruption of oncostatin M receptor results in altered hematopoiesis. Blood 2003;102:3154-3162. [PubMed: 12855584]

52. Wakitani S, Hondo E, Phichitraslip T, Stewart CL, Kiso Y. Upregulation of Indian hedgehog gene in the uterine epithelium by leukemia inhibitory factor during mouse implantation. J Reprod Dev 2008;54:113-116. [PubMed: 18239353]

53. Palmqvist P, Persson E, Conaway HH, Lerner UH. IL-6, leukemia inhibitory factor, and oncostatin $\mathrm{M}$ stimulate bone resorption and regulate the expression of receptor activator of NF-kappa B ligand, osteoprotegerin, and receptor activator of NF-kappa B in mouse calvariae. J Immunol 2002;169:3353-3362. [PubMed: 12218157] 
54. Xu D, Qu CK. Protein tyrosine phosphatases in the JAK/STAT pathway. Front Biosci 2008;13:49254932. [PubMed: 18508557]

55. Stephanou A, Scarabelli TM, Brar BK, Nakanishi Y, Matsumura M, Knight RA, Latchman DS. Induction of apoptosis and Fas receptor/Fas ligand expression by ischemia/reperfusion in cardiac myocytes requires serine 727 of the STAT-1 transcription factor but not tyrosine 701. J Biol Chem 2001;276:28340-28347. [PubMed: 11309387]

56. Simonaro CM, D'Angelo M, He X, Eliyahu E, Shtraizent N, Haskins ME, Schuchman EH. Mechanism of glycosaminoglycan-mediated bone and joint disease: implications for the mucopolysaccharidoses and other connective tissue diseases. Am J Pathol 2008;172:112-122. [PubMed: 18079441]

57. Rhee SH, Jones BW, Toshchakov V, Vogel SN, Fenton MJ. Toll-like receptors 2 and 4 activate STAT1 serine phosphorylation by distinct mechanisms in macrophages. J Biol Chem 2003;278:22506-22512. [PubMed: 12686553] 


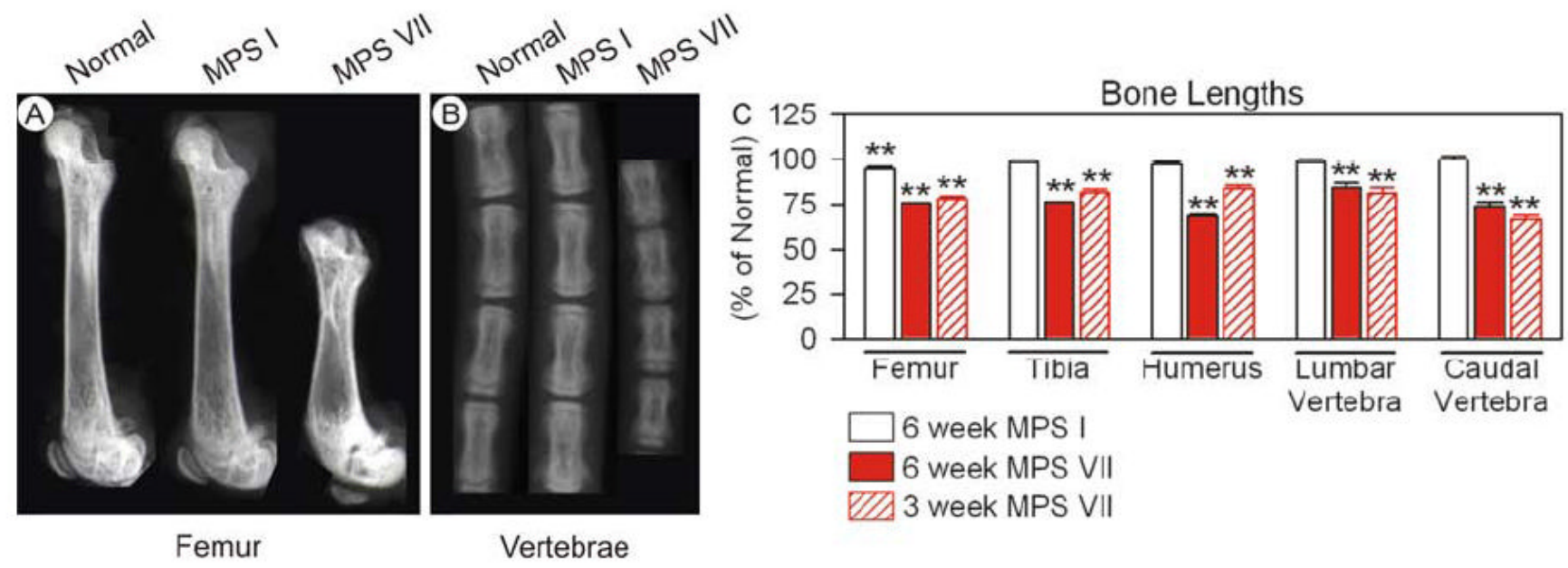

Fig. 1.

Mouse bone lengths. A and B. Representative radiographs of femurs and caudal vertebrae (6 through 9) from 6 week-old mice. C. Bone length measurements at 6 and 3 weeks. Measurements from 6 week normal $(\mathrm{N}=11)$, MPS I $(\mathrm{N}=9)$, and MPS VII $(\mathrm{N}=6)$ and 3 week normal $(\mathrm{N}=6)$ and MPS VII $(\mathrm{N}=7)$ bones are shown. For 6 week old mice, data for male and female mice were pooled and were normalized to the average length of the same bone in 6 week old normal mice, using one way ANOVA with Tukey post-hoc analysis for statistical comparisons. For 3 week old mice, all data were from males and the Student's $t$ test was used for statistical comparisons. P values compared to normal are labeled as ** for $\mathrm{p}<0.01$, and * for $\mathrm{p}=0.01-0.05$. Error bars indicate $\mathrm{SEM}$, and the dashed line indicates normal. The $2^{\text {nd }}$ lumbar vertebrae and the $8^{\text {th }}$ caudal vertebrae were measured. 

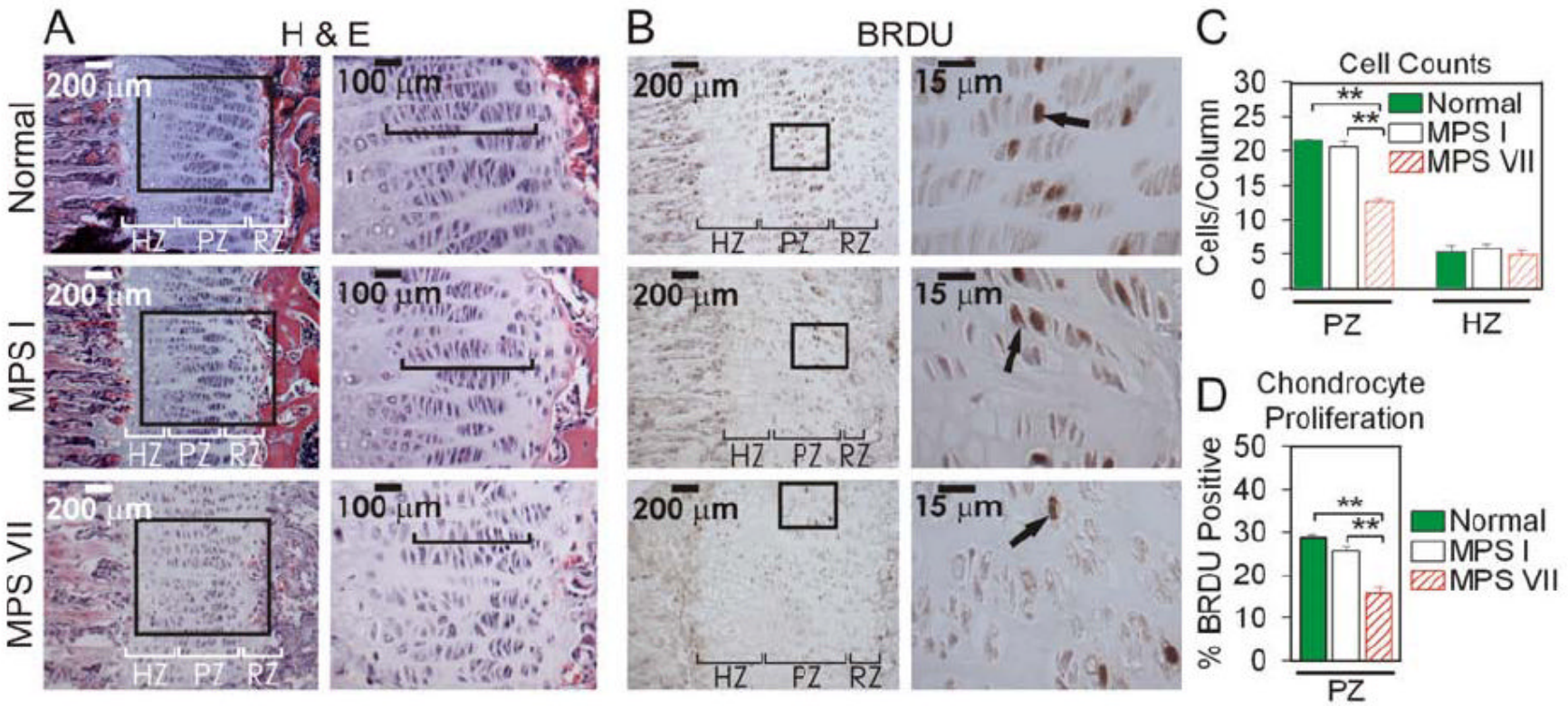

Fig. 2.

Histopathology and labeling index of proximal tibia growth plates. A. H \& E stains of tibia growth plates at 3 weeks of age. Black boxes indicate the region enlarged at the right. Brackets indicate hypertrophic zone (HZ), proliferating zone (PZ), and resting zone (RZ). Black brackets in column 2 show a representative chondrocyte column that was evaluated for the number of cells in the proliferating zone. B. BRDU staining of tibia growth plates at 3 weeks of age. Brown cells are BRDU-positive, as exemplified by black arrows. C. Quantification of the number of chondrocytes per column in normal ( $\mathrm{N}=9$ ), MPS I $(\mathrm{N}=5)$, and MPS VII $(\mathrm{N}=6)$ growth plates. Error bars represent SEM, and **: $\mathrm{p}<0.01$ for data sets connected by brackets using one way ANOVA with Tukey all-pairwise post-hoc analysis. D. Quantification of the percentage of BRDU positive cells in the proliferating zone of normal $(\mathrm{N}=5)$, MPS I $(\mathrm{N}=4)$, and MPS VII $(\mathrm{N}=4)$ growth plates. 

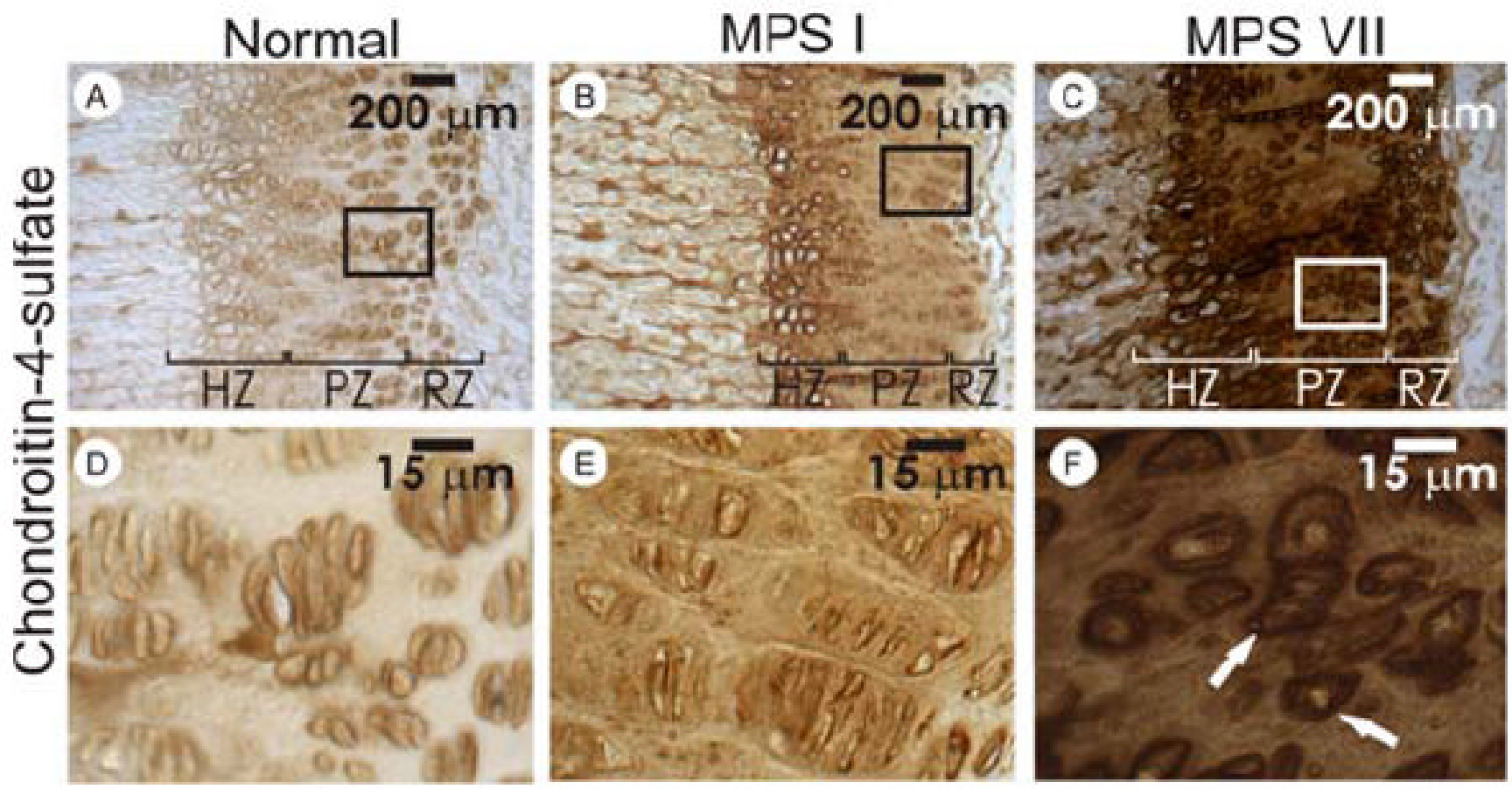

Fig. 3.

GAG immunohistochemistry on tibias of 3 week old mice. Chondroitin-4-sulfate was detected in growth plates by digestion with chondroitinase $\mathrm{AC}-\mathrm{I}$ (digests $\mathrm{C} 4 \mathrm{~S}$ and $\mathrm{C} 6 \mathrm{~S}$ ) followed by incubation with $\Delta$ di-4S antibody. Growth plate zones are designated as in Fig. 2. Boxes in A$\mathrm{C}$ indicate the regions of magnification shown in D-F. White arrows in panel $\mathrm{F}$ show examples of cells with excess C4S. C4S is also present in the extracellular space. Photographs are representative of results from 3 mice of each genotype. 
A

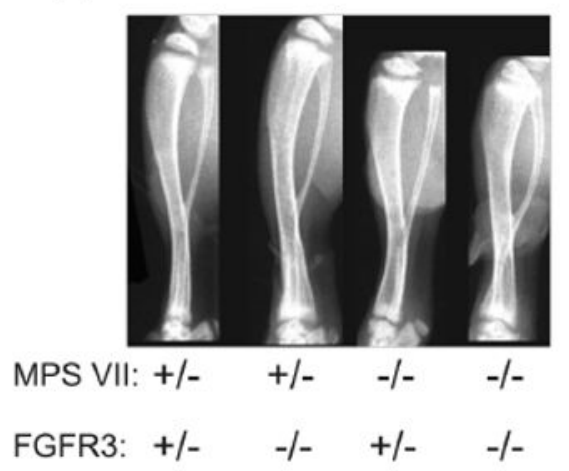

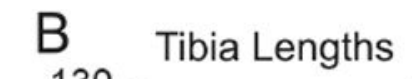

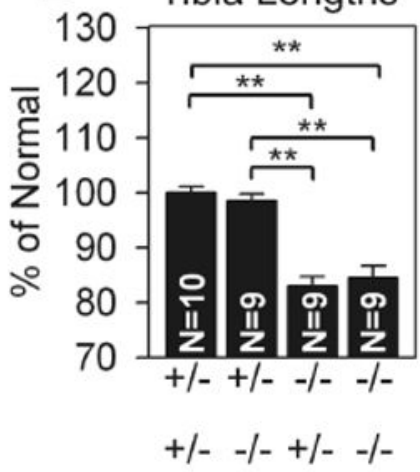

Fig. 4.

FGFR3 does not mediate bone shortening in MPS VII. A. Radiographs of normal (MPS VII +/-, FGFR3 +/-), MPS VII (MPS VII -/-, FGFR3 +/-), FGFR3-deficient (MPS VII +/-, FGFR3 $-/$ ), and MPS VII and FGFR3-deficient (MPS VII -/-, FGFR3 -/-) mouse tibias at 3 weeks of age. B. Length measurements of tibias from 3 week old male mice. Statistics were performed as in Fig. 2. 

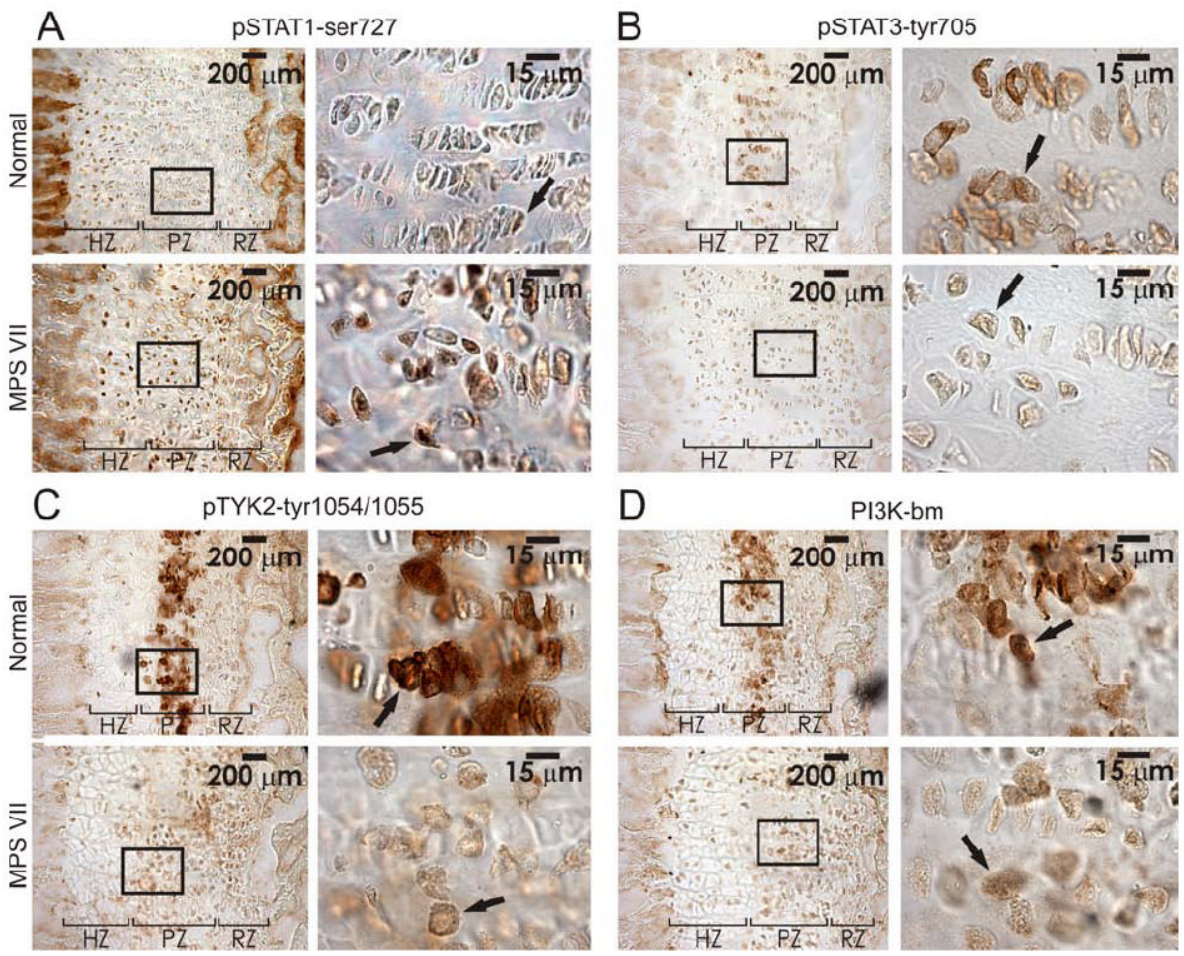

Fig. 5.

Immunohistochemistry of mouse tibia growth plates. Immunohistochemistry for the indicated antibodies was performed on 5 normal and 5 MPS VII growth plates at 3 weeks, and representative photographs of the growth plate and the proliferative zone are provided. Brown color signifies positive cells, which are indicated by black arrows. Black boxes in columns 1 and 3 indicate the region magnified in the image to its right. Growth plate zones are designated as in Fig. 2. 


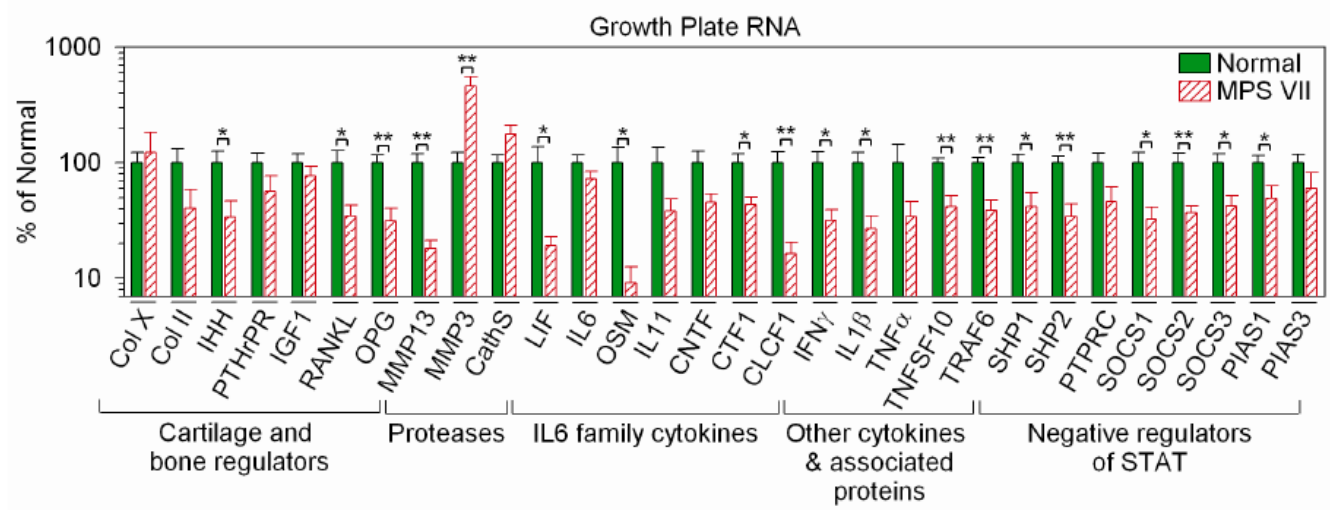

Fig. 6.

Evaluation of growth plate RNA from MPS VII and normal mice at 3 weeks of age. RNA was extracted from the head of the tibia, real-time reverse-transcription PCR was performed, and transcript expression was normalized to $\beta$ actin. Results are given here as a percentage of normal expression, while relative abundance of each gene is listed in the supplemental methods. $* *: \mathrm{p}<0.01, *: \mathrm{p}=0.01-0.05$ using Student's t test. Error bars indicate SEM. N=7 or more animals for each group. Genes tested are as follows: collagen X ( $\mathrm{Col} \mathrm{X})$, collagen II (Col II), indian hedgehog (IHH), parathyroid hormone related peptide receptor (PTHrPR), insulin-like growth factor 1 (IGF1), receptor activator for nuclear factor $\kappa B$ ligand (RANKL), osteoprotegerin (OPG), cathepsin S (CathS), matrix metallopeptidase 3 (MMP3), matrix metallopeptidase 13 (MMP13), leukemia inhibitory factor (LIF), interleukin 6 (IL6), oncostatin M (OSM), interleukin 11 (IL11), ciliary neurotrophic factor (CNTF), cardiotrophin 1 (CTF1), cardiotrophin-like cytokine factor 1 (CLCF1), interferon $\gamma$ (IFN $\gamma)$, interleukin $1 \beta$ (IL1 $\beta)$, tumor necrosis factor $\alpha(\mathrm{TNF} \alpha)$, tumor necrosis factor ligand superfamily member 10 (TNFSF10), tumor necrosis factor receptor-associated factor 6 (TRAF6), SH-domain containing phosphatase 1 (SHP1), SH-domain containing phosphatase 2 (SHP2), protein tyrosine phosphatase - receptor type C (PTPRC), suppressor of cytokine signaling 1 (SOCS1), suppressor of cytokine signaling 2 (SOCS2), suppressor of cytokine signaling 3 (SOCS3), protein inhibitor of activated STAT1 (PIAS1), and protein inhibitor of activated STAT3 (PIAS3). 


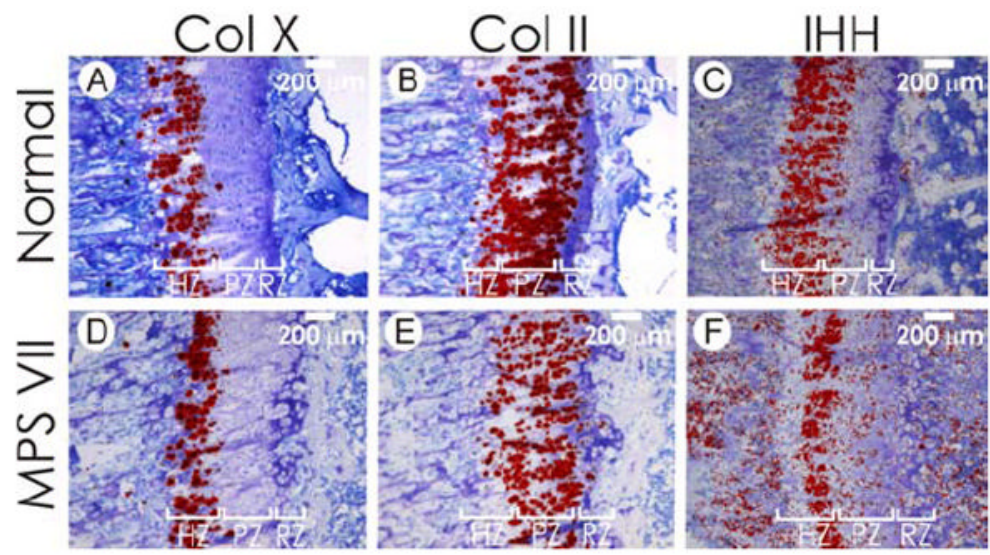

Fig. 7.

In-situ hybridization for Col X (A, D), Col II (B, E), and IHH (C, F). Representative photographs chosen from 3 normal and 3 MPS VII mice are shown, using identical exposure times for each gene in all samples. Red signal represents areas positive for the RNA of interest. The color was obtained by converting the signal seen in dark field to false color red, followed by overlaying the signal on an identical image in bright field. Growth plate zones are designated as in Fig. 2. 


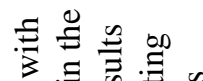

实矛芯

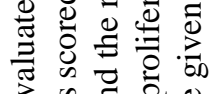

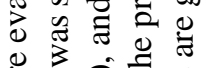

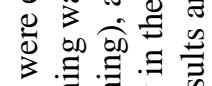

文寻寻文岕

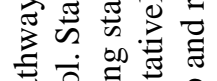

б

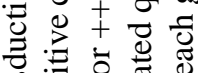

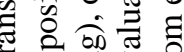

$\exists \frac{2}{3} . \Xi 20$

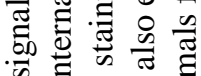

氙莺芯

त.

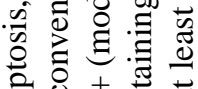

定 0

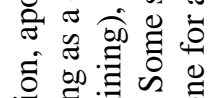

矛 恶

巳 屯

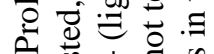

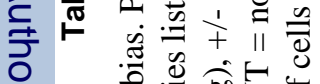

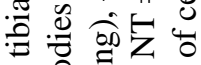

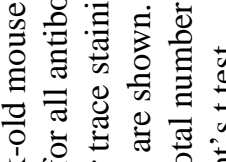

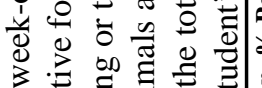

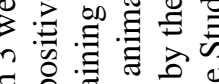

ㅇ ฉ

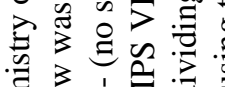

ह

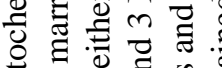

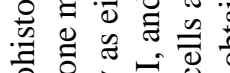

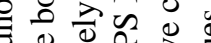

䒠导主

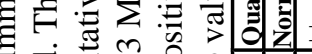

\& 0

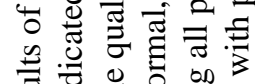

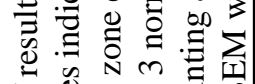

to

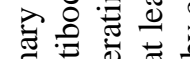

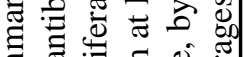

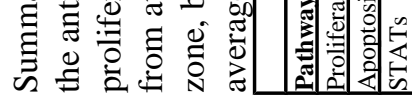

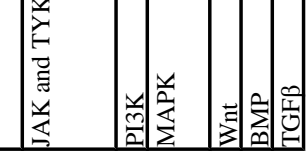

Mol Genet Metab. Author manuscript; available in PMC 2010 July 1. 